\title{
Manufacturing-Production Systems and Their Importance: Evaluation of Flexible Manufacturing Systems (FMS)
}

\author{
Ayşenur Erdi1 ${ }^{1 *}$

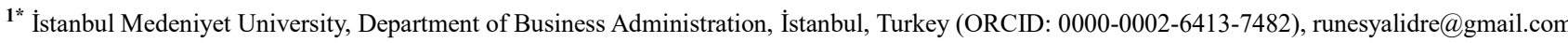 \\ (International Symposium on Multidisciplinary Studies and Innovative Technologies (ISMSIT) 2021 - 21-23 October 2021)
}

(DOI: $10.31590 /$ ejosat.1024198)

\begin{abstract}
ATIF/REFERENCE: Erdil, A. (2021). Manufacturing-Production Systems and Their Importance: Evaluation of Flexible
\end{abstract} Manufacturing Systems (FMS), European Journal of Science and Technology, (29), 331-342.

\begin{abstract}
Flexible manufacturing systems (FMS), transitional or absolute customer to encounter the various requirements and preferences, helping to protect organizations which in the circumstances of competitive environment in eachother exactly known always to created, are constructed as a structure that could really keep producing various products and services with minor modifications. Computers are used to help manufacturing lines. This research provides the literature review of manufacturing-production systems, categorisation of manufacturing techniques, advanced manufacturing technologies, manufacturing process modeling, modeling definitions, and database organizational structures, data regulations and procurement for Flexible Manufacturing Systems-Techniques, and eventually the research conclusion and recommendation. Mostly with significant developments in the manufacturing sector, the database idea has become an essential and fundamental element of every type of production system. Its most fundamental tasks are the preservation and accessibility of services required to regulate industrial operations. This study also utilizes SWOT (Strengths, Weaknesses, Opportunities, and Threats) evaluation to explore the appropriateness of manufacturing techniques, FMS in industrial manufacturing automated processes. The highlighted elements indicate manufacturing systems' considerable potential to address advanced manufacturing modernization challenges.
\end{abstract}

Keywords: Flexible Manufacturing Systems, Manufacturing-Production, Manufacturing systems, SWOT Analysis

\section{İmalat-Üretim Sistemleri ve Önemi: Esnek İmalat Sistemlerinin (EİS-EÜS) Değerlendirilmesi}

$\ddot{O} \mathbf{z}$

Esnek üretim sistemleri (EİS), ara veya nihai tüketicinin farklı talep ve ihtiyaçlarını karşılayabilecek, rekabet koşullarında kendilerini koruyan işletmelerde şimdiye kadar yapılmış, yapılacak küçük değişikliklerle farklı mal ve hizmetler üretebilecek bir sistem olarak tasarlanmaktadır. Üretim hatları bilgisayar desteklidir. Bu araştırma, imalat sistemleri, imalat tekniklerinin sınıflandırılması, ileri imalat teknolojileri, imalat süreci modellemesi, modelleme tanımları ve veri tabanı organizasyon yapıları, Esnek İmalat Teknikleri için veri düzenlemeleri ve tedariki ile ilgili literatür taraması ve nihayetinde araştırma sonucu ve tavsiyesi sunmaktadır. İmalat sektöründeki önemli gelişmelerle birlikte, veri tabanı fikri her tür üretim sisteminin vazgeçilmez ve temel bir unsuru haline geldi. En temel görevleri, endüstriyel operasyonları düzenlemek için gerekli hizmetlerin korunması ve erişilebilir olmasıdır. Bu çalışma aynı zamanda endüstriyel üretim otomatik süreçlerinde üretim tekniklerinin ve Esnek Üretim sistemlerinin (EÜS) uygunluğunu araştırmak için bir SWOT-GZFT (Güçlü Yönler, Zayıf Yönler, Fırsatlar ve Tehditler) değerlendirmesinden yararlanmaktadır. Vurgulanan unsurlar, üretim sistemlerinin ileri üretim modernizasyon zorluklarını ele alma potansiyelini göstermektedir.

Anahtar Kelimeler: Esnek İmalat Sistemleri, İmalat-Üretim, İmalat Sistemleri, SWOT-GZFT Analizi.

\footnotetext{
* Corresponding Author: İstanbul Medeniyet University, Department of Business Administration, İstanbul, Turkey (ORCID: 0000-0002-6413-7482), runesyalidre@gmail.com
} 


\section{Introduction}

As earlier as 1815, an idealistic socialist used the expression "manufacturing system" to describe to a "factory system." In 1961, the manufacturing process was envisioned as the synchronization of manufacturing science and engineering into a succession of development, computing, control system, equipment, and fabricating operations.Manufacturing technologies are classified as mass, batch, or jobbing manufacturing. Aside from Manufacturing Systems-MS, Manufacturing Technology Structures (Machine Cell, Manufacturing Cell, Flexible Manufacturing Systems- FMS, Flexible Transfer Lines -FTL, and Flexible Assembly LinesFLA), Manufacturing System Modelling, and Data Structures would be investigated in this study (Hitomi, 1996; Merchant, 1961).

The phrase manufacturing could apply to the movement and reaction-based manufacture of polymers, nylon yarn, garments, and compounds. procedure. Researchers are intrigued in that aspect of the whole production process, as well as the goods. Trying to cast or forming, as well as rolling or drawing sheets or panel, would often be used to make the materials. For the completed goods to be produced, a number of processes must be performed on the constituents. These processes can include a wide variety of trying to form and processing procedures, such as cleaning and inspection. When the components are ready, they are frequently combined into subassemblies until being integrated together. As stated recently, the actual definition of manufacturing was to produce items by means. Nevertheless, the current definition is far broader: manufacturing refers to 'the translation of a design into a finished product,' whilst 'production' refers to the practical process of creating the thing. Manufacturing was defined by CIRP - International Conference on Production Research in 1983 as a number of connected functions and processes associated with the design, selection of components, making plans, manufacturing, process improvement, evaluation, and industry research of manufacturing industries' products (Merchant, 1961; Young and Mayer, 1984; Merchant, 1983, Merchant, 2000).

Manufacturing includes the three key features listed orderly. (i) Delivering fundamental necessities for mortal survival. A human being cannot live without the manufacturing process or manufacturing of products, and this is becoming largely relevant in contemporary society. (ii) The accumulation of collective resources. Manufacturing generates a government's or nation's earnings. When a region's manufacturing base is depleted, it becomes poor and desperate. (iii) Initiatives to enhances community satisfaction and global peace. A economically successful and productive continent could provide its individuals with protection, social assistance, and satisfaction (Hitomi, 1994; Hitomi, 1996). This research is associated with manufacturing systems for product lines with multiple individual components. Generating the involved parties necessitates a number of activities that are performed on the ingredients. Furthermore, the study will focus on how the concepts and mathematical analysis expressed could be implemented broadly.

\section{Material and Method}

\subsection{Categorization of Manufacturing Technologies - Systems}

The production-manufacturing systems used to produce the goods are typically divided into three categories. There are three types of production systems: mass production, batch production, and jobbing production and also in addition continous production. The defination of these are as below (Buzacott, 1983; Browne et al., 1990; Bowden and Browne, 1991; Types of production, 2021).

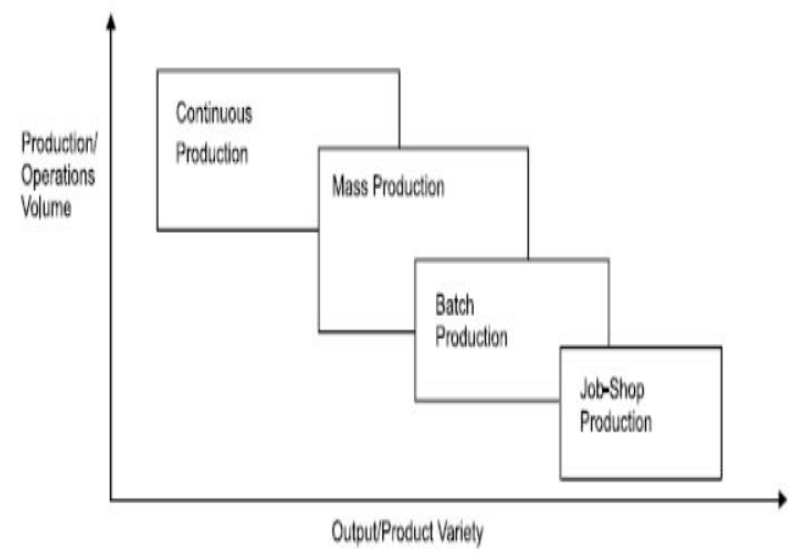

Figure 1. Relationship between classification, Production System Categories - Types of Production Systems (Types of production, https://theintactone.com/2019/06/16/pom-u1-topic2-types-of-production-systems/)

An organization's production system is indeed the component that generates the company's processes. It is the operation in which facilities moving inside a structured framework are integrated and converted in a controllable environment to generate profit in accordance with management's regulations. Here is a simplification production process. The following components are shared by the manufacturing systems (Types of production, 2021; Groover, 2015; Bowden and Browne, 1991):

i. Because manufacturing is an integrative process, every production system seems to have a goal.

ii. The process converts the output signals into appropriate capacitance.

iii. It it does not even not operate autonomously of the other organizational systems.

iv. There is comments about the events, which is critical for controlling and improving performance of the system.

Manufacturing systems are classified as Job Shop, Batch, Mass, or Continuous Production systems (Buzacott, 1983; Browne et al., 1990; Bowden and Browne, 1991; Groover, 2015; Types of production, 2021).

\subsubsection{Large-Scale Productıon-Mass Productıon}

Mass manufacturing is a type of manufacturing wherein goods are constantly generated by special-purpose machines. When machines really aren't expected to perform anything at all, they could be specialized, and significant sophistication and expenditures could be invested in their development and installation to maintain they function properly. The attributes of 
mass production included "fixed mechanisation." The automation is unchangeable, and the machines are regarded to as "committed" to their successful result. Simple products could be massproduced on a single machine, although most complicated components necessitate an interconnected number of actions. This technique of connecting sequential operational activities and manufacturing is commonly referred to as flow production. Even though product lines of mass production are clearly visible on everyones roadways and in todays households, the number of business are not required in these large amounts and are generated in batches. Depending on the number constituent amount required, specialized tooling, lighting, and grounding straps might well be shown on the machines. The significantly larger the quantity, the more specialized the equipment (Browne et al., 1990; Bowden and Browne, 1991; Qiao et al., 2006; Groover, 2015; Types of production, 2021).

\subsubsection{Batch Production}

When the necessary product quantities are insufficient to allow uninterrupted manufacturing of one product on specialized machinery, batch production is used. More specific machines that can be reconfigured to manufacture a variety of different components in varying batch numbers must be utilized. Improvements have been accomplished in the technology of the machines and the equipment they utilize, as well as in the manufacturing operation. These advancements have been developed to address some of the major issues associated with batch manufacturing. In batch manufacturing, each machine is typically assigned one operator. If the operator departs the machine for whatever purpose, this should halt and the machine's utilization would suffer as a result. Machines must be reconfigured between batches in batch manufacturing. The evolution of batch manufacturing could be tracked in the same way that the evolution of a system could be with mass production. Phases in its early development are much more related to the creation of the various types of machine tools which are seen in the industrial business these days (Hitomi, 1996; Groover, 2015; Hannam and Talavage, 2020).

The use of group technology (GT), the use of coordinate measuring equipment, and the implementation of advanced processing workstations to batch production issues. Because components go along machine to machine and subsequently exit the cell, group technology may be defined as a method of converting batch manufacturing to a type of flow-line production. Though components are still produced in groups, the decreased set-up time and processing times imply that it is frequently sufficient to decrease batch sizes, resulting in much more manufacturing technologies. Most GT machine operations use manual part/batch processing together within cellular and depend on machine closeness to make decisions (Hannam and Talavage, 2020).

\subsubsection{Job-Jobbing Production}

Many products and materials are really only needed in tiny amounts, and "jobbing techniques" create them. For small lot sizes manufacturing, specialized manufacturing, fixings, and pressure transducers are typically not warranted, and commercially available machines and equipment are utilized in conjunction with manual processes. Job production focuses on creating a single product from conception to finish. When one product is finished, another might be started. It's indeed extremely specialized and labor consuming. Depending on the scale of the business, a particular item could be manufactured using approaches from all three categories. Products that are made using jobbing techniques are considerably more expensive than those made by mass manufacturing processes, but they serve the demands of a more specialized and restricted top of the business where buyers can afford to cover higher costs. It is related to high goods, custom requests, and one-of-a-kind things. Clothing produced to order is one instance of job production. Job manufacturing is typically complex and expensive, and highly qualified labor is frequently necessary. Building ships, bridges, and structures are instances, as are manufactured handicrafts such as furniture and produced clothing. Job production, in which products are manufactured one at a time and each one is completed before the next one is begun (Groover, 2015; Methods of production, 2021; Simplicable, 2021; What is job production process; 2021).

\subsection{Advanced Manufacturing Systems}

Automation Manufacturing has raised the overall quality of life by lowering product costs. Although, employment has indeed been created; unfortunately, the nature of the work has changed, and the transformation in automation involves industrial and social ramifications. Manufacturing breakthroughs result in development, affecting all parts of life from the factory floor to the workplace and home. In the workplace, automated production systems work on the physical product. They carry out processes such as manufacturing, assembling, verification, and handling of materials, and in many instances carry out several processes in the same platform. They are considered autonomous because they conduct their activities with less human interference than the comparable manual procedure. There is almost no individual participation in certain extremely automation systems(Groover , 2015; Merchant, 2000). Flexible Manufacturing Systems (FMS) is the most advanced form of integrated manufacturing process. FMS has been extended to several innovative and effective manufacturing techniques that were created at the time in the late 1960 s and early 1970s. Manufacturing systems are flexibility if they can process a variety of different workpiece material concurrently and automatically, with the machines in the system accepting and carrying out the procedures on the workpiece surface in any arrangement. FMS are complicated, and it is simpler to explain them than it is to describe them. Single things may be manufactured on single machines, but more complicated products need a connected series of processes, and manufacturing by this technique is typically more expensive (Barry , 1986; Tetzlaff, 1990; Barad, 1992; Groover , 2015).

\subsubsection{Producing -Manufacturing Cells}

A manufacturing cell is a collection of processing elements that work together to complete a family of components without exiting the cellular. The cell's development is typically influenced by the specifications of the component group. A cell is made up of several CNC workstations, an automaton, and a material and/or equipment handling system. Loading and unloading of parts and components, processing scheduling of components, tools, and machines, established, and transferring of parts and components are all essential cellular processes. Even just a tiny cell has numerous operations that must be managed and synchronized in order for the manufacturing organisation to succeed. The fundamental tasks of a cellular control system might vary depending on the size and capabilities of the cell, as well as the degree of decision - making process capabilities. The main tasks of the cellular control system seem to be to schedule operations, 
workstations, containers, equipment, and other materials. These operations are also utilized for scheduling, performances, resource infrastructure investments, quality, manufacturing orders, production units, and equipments (Barad, 1992; Barry, 1986).

Each Flexible Manufacturing Systems (FMS) is made up of two or even more cells. A cell is a type of processing element or operational node in decentralized FMS computer systems. Each cell ought to be able to autonomously change components and/or tools, and it should be capable of communicating with the "outside environment" in terms of both data acquisition and the material management system. The Manufacturing Cell is split into three sections: Palletised Cellular is the first one. It is typically used for slightly elevated, low-volume issues. Material handling combines a variety of versatile fundamental mechanical equipment. They use a standard pallet construction with pre-fixed pieces on pallets. Palletised cells are restricted to two or three units due to component flow logistics. A FMS is a collection of machines... linked by a transportation system. FMS is made up of a collection of processing units that are linked together by an automated material - handling platform and are managed by an incorporated computer control system. A FMS is made up of numerous machine tools, as well as part and process handling devices including robots, that are organized in such a way that they may handle any variety of components for which they were designed and implemented (Barry, 1986. Shivanand et al., 2006). The second type is the FMS cell. The automated movement of raw resources to the cell, complete processing of the component across the machines within the cell, and finally extraction of the finished part are the distinctive features of this cell. Materialhandling systems might connect several kinds of cells in a significantly larger automated processes system. The third component of the cellular, the robot or autonomous cell, is used for high volume manufacturing of tiny, well-defined, homogeneous families of components. They are made up of a set of flexible machines that are coupled with robots or specialized material handling. There's many fixed processes in these cells, and components pass progressively through activities. Through the use of robots, powered fastening of components, specific equipment, and other types of automating, the cell is transformed into an entirely automated operation (Browne et al., 1884; Cutkosky et al., 1984; Spur et al., 1986; Luggen, 1991).

\subsubsection{Flexible Manufacturing Systems (FMS)}

A Flexible Manufacturing System (FMS) is a system that deals with high-level decentralised data handling and automated material management utilizing computer-controlled machines, assembly cell lines, integrated circuits, evaluation machines, and so on, in conjunction with computer-integrated components packaging and processing processes. FMS could also relate to a flexible, thoroughly automated process, but it is also used here to describe to a manufacturing approach that helps for automated systems and a high degree of customization in the manufacturing of components in batch processes. FMS could be used by manufacturing enterprises of all sizes to reduce warehousing or increase throughput to meet client demands. A production system is versatile if it can operate several workpieces at the same time and autonomously. In the categorization of FMS, four fundamental patterns may be found (Yang et al., 2005; Luggen, 1991; . BaneIjee and AI-Maliki, 1988; Barry, 1986; Johnson, L.A. and Montgomery, 1974).

i) Flexible Manufacturing Module: a Computer Numerical Control (CNC) machine equipment, a workpiece transportation e-ISSN: 2148-2683 system, and a machining remote monitoring are all part of this subsystem.

ii) Flexible Manufacturing Cell: two CNC machine equipment, a workpiece transferring or industrial robot, and a distribution center for component transportation are included.

iii) FMS Automated equipment: an intelligent transferring interface provides the movement of workpieces.

iv) FMS Manufacturing Factory: all manufacturing operations have indeed been converted to FMS.

The advantages of FMS include: improved performance, reduced cost of production, reduced inventory and WIP to predetermined levels unheard of, reduced repeating, often dangerous, physically demanding work, with an improved the need artificially intelligent research, batch size of one, consequently offering flexibility and efficiency previously unimagined (5 Principles of Flexible Assembly Line Design, 2021; Yang et al., 2005; Berry and Cooper , 1999; Luggen, 1991; . BaneIjee and AI-Maliki, 1988; Barry, 1986; Johnson, L.A. and Montgomery, 1974).
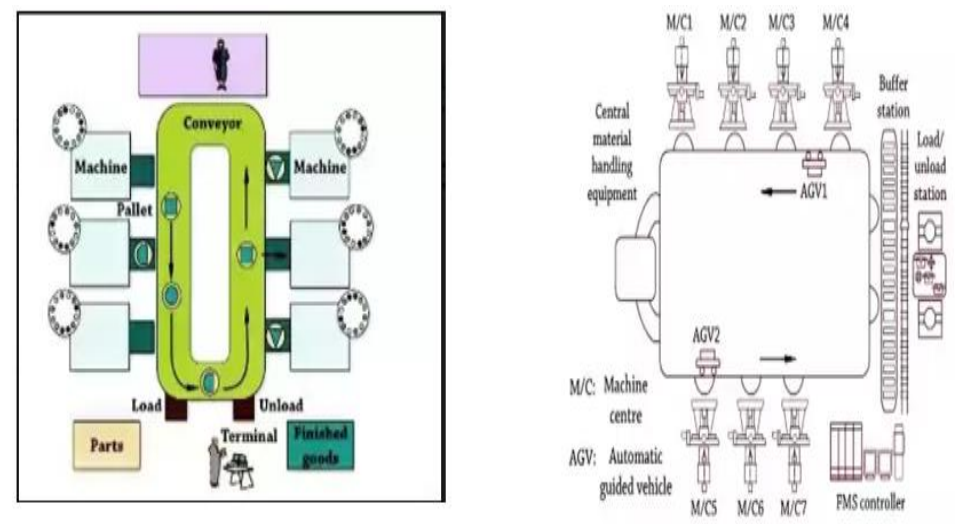

\section{Figure 2. Flexible Manufacturing System Facility (Flexible Manufacturing System, \\ https://www.mechtalk.info/2018/11/flexible-manufacturing- system-fms.html)}

A flexible manufacturing system (FMS) is a largely computerized cellular manufacturing cells comprised of a collection of operating terminals linked by an automation material handling technology and operated by a computer network. This fundamental FMS structure arrangements are presented in Figure 2. FMS is a manufacturing process consists of multi manufacturing equipment that have combined control system and an automatic material handling designated representative (Luggen, 1991; Flexible Manufacturing System, 2021). An FMS often includes an automated assembly system (AMHS) and computerized numerical control equipment (McGinnis, 1989). To rationalize the high initial investment of an FMS, appropriate system framework is needed.

\subsubsection{Flexible Transfer Lines (FTL)}

The concepts of flow line manufacturing are used to machining processes in transferring machines and connect line segments. High intensity performance is dominated by transferring machines by splitting the manufacturing of a component into a multitude of specialized operations that are performed out consecutively at a succession of specialized workspaces. Workplaces are placed in a line (or a circle), and components are manufactured at the same time, with the specific conventional machining determined with how far a part has gone 
across the line. At the conclusion of each processing cycle, all components are moved towards the next workspace at the same time, with a completed component exiting the line and an unmachined part entering. Transferring machines are often used to perform drilling, tapping, boring, milling, and trying to approach processes on parts that began life as castings or forgings. Workstations often feature only a single axis of rotation because this is all which is necessary for such tasks. Components that need turning, cylinder cutting, gear cutting, or similar processes are not typically manufactured on a transfer line since these activities necessitate revolving in various directions. Transferring machineries and connect lines use the same flow line concepts. The primary difference in how the concepts are applied is that link lines use full industrial equipment, whilst transfer machines use specialised machining components. Transfer Techniques are extremely specialized and devoted permanent automating pieces. Attempting to alter them, on the other hand, is difficult and costly (Yang et al., 2005; Luggen, 1991; . BaneIjee and AI-Maliki, 1988; Barry, 1986; Johnson, L.A. and Montgomery, 1974).

\subsubsection{Flexible Assebly Lines (FAL)}

In an ideal world, eliminating assembly completely would be the greatest approach. Assembly lines are a form of FMS since the bulk of assembly is done manually, and a human operator with a variety of powered tools is one of the most adaptable "systems" available. Devices that can be reconfigured to allow flexible assembly machines to readily respond to disruptions and economic cycles. On conveying lines or overhead cranes, the assembly line transports items from station to station. Employees, and progressively robots and acts as an insulator - robots which can travel effectively in close enough proximity to people complete their task when the work in process goes to a new station until the product is transported to the next stop. The principles and regulations of the assembly are as follows ( 5 Principles of Flexible Assembly Line Design, 2021; Banker , 2018; Michalos et al., 2016; ; Sawik, 1999; Luggen, 1991; . BaneIjee and AIMaliki, 1988);

i. One-dimensional assembling, often known as "z-stacking," is preferable over many axes. Most of the time, this situation could be guaranteed by design.

ii. The mechanical components used should be reduced or removed.

iii. Excess weight should also be avoided by thorough construction and structural distribution.

iv. To reduce weight and improve quality, compatible and/or alternative materials such as plastics, HSLA superalloys, composites, and so on might be explored.

v. Parts should indeed be constructed in such a way that their alignment is constant and permanent.

Because manufacturing consistency needs are expensive, measurements should really be specified with as few tolerances as feasible while remaining compatible only with product performance standards and the consistency. reputability of the relevant requirement. A flexible assembly line (FAL) is a manufacturing system with unidirectional flow. It is made up of a sequence of assembly steps that are either separated from the rest by defined exhaust nozzle buffering or have no intermediary buffers between them. Each phase has one or more parallel computers that are identical. The line could create several distinct part kinds at the same time. Each phase requires at least one machine to manufacture each item, however certain parts might bypass several phases. Queuing throughout assembling phases is permitted in the line with restricted intermediary reserves, but it is not permitted in the line with no buffer solutions. A flexibility assembly line is a hybrid of traditional methods Because of its practical relevance and theoretical difficulty, flexible assembly lines are acquiring substantial value. In practice, firms could employ flexible assembly lines to maintain high performance and adapt towards ever client needs in order to stay competitive. Automation systems, including such robots or computational numerically controlled machines, could do more complicated and accurate assembling jobs in less time (Banker, 2018; Michalos et al., 2016; Barutçuoğlu and Azizoğlu, 2011; Sawik, 1999).

\subsection{Modeling of Manufacturing Systems}

A model is a conceptual depiction of a real-world event or behavior using appropriate language or expressions. In generally, it is less complicated than actuality. In a nutshell, a model is a representation and modification of reality. Because hardware experimentation is complicated and expensive, individuals are encouraged to modeling intelligence to assess the behavior of industrial systems. In the design and operating phases of a system, modeling techniques are used to evaluate it. A modeling must explain the system's behavior while predicting the potential altering consequences. The model merely represents select aspects of the system and concentrates on those aspects of the system. As previously said, the model is lighter than the centralized database since a more complicated model takes longer to construct and a much more complex model takes longer to comprehend, evaluate, and comprehend the outputs. The model, on the other hand, does not have to be overly basic. Because if it is too basic, it may be incorrect and perform poorly, and so may not accurately portray actuality Models are classified according to form, the system objective, the time nature and the variability according to Solberg. The first step in modeling is to create a model that represents the system's behavior. The goal of model construction is to follow the model's behavior while also estimating the possible changing results. It is critical for the designer/engineer to realize that the model could only contain some system aspects and can only concentrate on those system components which might impact progress and manage the effect of the external components that concern the designer/engineer. The model must be a simplified perception of events. This is due to a number of factors. To begin with, a more complicated model requires more time to construct (Askin and Standridge, 1993; KouveJis , 1992; Schorer and Tseng, 1987; Solberg, 1976).

For the purpose of simplicity, basic modelling methodology is defines as below, : Analytical Modelling. Simulation Modelling, Algorithmic Modelling and Al Based Modelling. Furthermore, a more complicated model is much more difficult to comprehend since the method the many factors impact performance might include intricate relationships that are challenging to see. On the other side, if the model is too basic, its performance representation could be completely incorrect, and the model might not even represent all of the essential design and operational decisions. According to Solberg, models are categorized based on their structure, system aim, temporal nature, and unpredictability. To keep things simple, The researchers just cover the fundamentals of modeling: Analytical modeling is a term that refers to the process of creating a model Simulation modeling, Algorithmic modeling, and Algorithm Based Modeling are all types of 
modeling and Al Based Modelling (Solberg, 1979; Solberg, 1976; Schorer and Tseng, 1987).

\subsubsection{Analytical Modelling}

Analytical models are created at the start of the modeling process. Analytical models don't really represent precise occurrences, but instead just provide for fast performance assessment. The model may be created fast by eliminating complexity and compressing the assumptions, although these models are commonly criticized for their absence of consistency and accessibility. It swiftly assesses the system. As a result, analytical modeling is often chastised for its lack of seriousness and accessibility. Analytical modeling entails the modeling approaches listed as following orderly: Mathematical Programming; Queuing Networks; Static Capacity Analysis; Heuristic Algorithms; Semi-Markov Processes; Petri Nets (Buzacott, 1983; Wang, 1989; Askin and Standridge, 1993).

Because many analytical models are complicated, approximating approaches must be used to solve them. Though there are certain fundamental principles, developing approximation models needs great imagination. It is frequently impossible to evaluate approximation models directly, thus they must be evaluated by comparing their forecasts to those of other approaches. Mathematical modeling is frequently used to simulate automated industrial processes. Building a mathematical model is simple and requires little computational work. It also offers the system a rapid reaction. The fundamental approaches of mathematical modeling include linear, nonlinear, and dynamic programming. The mathematical modeling is believed to be untrustworthy owing to its restricted degree of output, simplicity, and problems in modeling various elements of manufacturing systems. On the other hand, they are still favored modeling tools because they provide a rapid reaction and are less expensive than other modeling tools (Stecke, 1983; Askin and Standridge, 1993). Queuing Network: Using a reliable analytic tool in design scenarios can save time, attention, and money over the long term. Such a device should offer performance indicators similar to those obtained from modeling, but with far less comprehensive data. Queuing Network is the name of this modeling tool. It examines a manufacturing system's steady-state behavior. It gives approximations by providing a particular level of detail and precision (Jackson, 1962; Baskett et al., 1975; Gordon and Newell, 1967). The queueing models used in automated production modeling, even including Solot and Bastos, Baskett et aI.,1975; Gordon and Well (1967) and Schweitzer (1977). Solberg (1976), (1978),(1982) created the first FMS layout approach based on controlled queueing networks. The Computer Analysis of Queuing Network (CAN-Q), a Queuing Network model, is utilized to estimate manufacturing system production capacity, machine utilization, queuing development progresses, flow time, and so on. For the single component type situation, the platform virtualization scheme is developed in CAN-Q. The results of the CAN-Q Analysis are the manufacturing frequency, the average time which the components occupy in the route, the bottleneck station, and the altitude. Static Capacity Analysis (SCAN) is another analytical modelling tool. It is used to compute the station, transportation, tool, job requirements and work in process in manufacturing system. These areas of calculation of the model are: - station requirements, - transport requirements, works in process, - job requirements, and - tool requirements. Another analytical modeling method is static capacity analysis (SCAN). It is employed in the production system to determine the station, transportation, instrument, job needs, and work in process. The following elements of the model's computation are: - station needs, - transportation needs- requirements, - works in progressprocess, - employment conditions, and - tool specificationsrequirements (Newman, 1990). The Heuristic Algorithm is utilized to handle particular problems like scheduling and equipment overloading. Knowledge-based systems (KBS) have served as the foundation for 'heuristic algorithms' in computerbased solutions, and it is these heuristics that regulation KBS are meant to manage (Grant, 1986). Stecke and Kim (1986) studied part type selection, machine grouping, production ratio, resource allocation and loading problems for FMS using several heuristic algorithm. Petri Nets is a technique for modeling the dynamic behavior of discrete concurrent systems. As a result, it is a straightforward tool for simulating component movement through a production system. Parallelism and concurrency may be handled via Petri Nets (Alla et al., 1985).

\subsubsection{Simulation Modelling}

Simulation modeling is the most commonly utilized modeling approach in the design of flexible and computerized production systems because of its complexity. It has a wide range of computer assistance and is a dependable modelling approach for complicated industrial systems. Machines simulate workpieces going from machine to machine in a real-world location in simulation modeling. Simulation modeling is a valuable modeling technique because it may committees established into the behavior of systems that are still in the design stage. Another advantage of simulation modeling is that it may push the consumer to consider about the process in greater depth than was previously the case. Optimisation models are the pinnacle of the simulation approach. They give such a deep insight into the whole system which they may be utilized as the framework for the completed installation's monitoring systems. On the other hand, while simulation or emulation models offer a more realistic image of the complete system, simulation is not an optimization tool, and the amount of dependent variables in developing any computerized manufacturing operations is often quite high. There are three methods for creating a simulation model: network, base, and data-driven. The network models were created to demonstrate the modeling process, however they could potentially be limited in their capacity to reflect the real world because they only give a limited amount of graphical symbols to do so. Network methods are simple to use but need some programming knowledge. The second technique in simulation modeling is the foundation paradigm. It necessitates considerable effort, possesses comprehensive modeling capabilities, and necessitates a lengthy training time for competent use. Simulation might well be thought of as an input-output procedure in which both the input and output are made up of configurations of knowledge. The model is represented in the input variety of facts, as is control of the simulation process. The data obtained from the run is contained in the output set of information. Simulation modeling is not an optimization approach, but it does provide 
more accurate outcomes of production processes, such as the number of people waiting for each machine at any one time, machine usage, and so on (Hannam and Talavage, 2020; Carrie, 1989; Law, 1988; Schorer and Tseng, 1987; Schorer and Tseng, 1987; Newman, 1990; Wang, 1989). Carrie (1989), Law (1988), Schorer and Tseng (1987), Newman (1990), and Wang (1989) investigated the evolution of simulation methods and their use in production. Zhang (1989) categorized simulation languages based on their simulation methods to real-world systems. They are as follows: i. Discrete-Event. three-phase time increment scheme. Scans the activities before terminating to complete. ii. DiscreteEvent. A two-phase system that combines the preceding two stages. iii. Continuous systems in which the actions are described using a process type.

\subsubsection{Algorithmic Modelling}

Another modeling technique with achievable and acceptable outcomes is Algorithmic Modeling. It is capable of recording and using the outputs of production systems. Algorithmic Modelling is concerned with the scheduling of event chains. Another possible and appropriate way to modeling industrial processes in depth and effectively is the algorithmic method (Stecke and Kim, 1986).

\subsubsection{Artificial Intelligence (Al) Based Modelling}

Artificial Intelligence (Al) is also used to simulate system behavior by combining it with human intelligence. Deep learning,-machine learning, pattern matching, and human behavior modeling are all part of the $\mathrm{Al}$ Methodology.Computers are used in $\mathrm{Al}$ Based Modelling to do representational understanding. It use imprecise or ill-defined information towards solving problems. It looks at qualitative aspects of techniques rather than quantitative ones. The results of Al Based Modeling are not accurate nor ideal, but they are appropriate. The algorithms handle with the sequencing of event sequences and serve as the foundation for system modeling. The algorithmic method offers a solid tool for designing, controlling, and operating industrial systems in a realistic way. Unlike simulation, this technique can capture, modify, and output significant volumes of user-specific data on the functioning of industrial systems, in addition to the standard statistical-based outputs received through simulation (Luger and Stubblefield, 1989; Zhang, 1989; Andert, 1992).

Manufacturing processes have previously benefited from expert system approach. There is now a lot of interest in various expert system applications for process planning, marketing and advertising, financial management, and production planning all over the world. To address the planning and scheduling difficulties, all approaches are employed. The combination of Al Based Models with simulation and graphical visualization has made them more convincing. s. Despite the diversity of issues addressed in AI research, a number of key traits emerge that appear to be shared by all segments of the discipline, including (Newell and Simon, 1963; Luger and Stubblefield , 1989; Nand, 1991; Groover, 2015).

- the utilization of computers to do representational thinking; - the emphasis on issues which do not yield to algorithmic resolutions;

- solving problems with unscientific, incomplete, or inadequately specified information including the use of representation approach to accommodate for these issues,

- an attempt to identify and modify key subjective aspects of a situation instead of depending on numerical approaches,
- solutions which are neither accurate nor ideal, but are "adequate" in some way

- the utilize of a vast quantity of domain-specific knowledge to issue solving; - the application of met a-level knowledge to influence more complex control of problem-solving techniques.

\subsection{Database Management Systems (DBMS)}

A database in an Flexible Manufacturing System (FMS) serves the purpose of storing and making available information required to regulate the manufacturing operation. A database is essentially a data collection stored in a huge number of computer files. Databases have logical structure and function in concert with software applications to provide a manufactured data system facilitating factory operating or design process that may service several applications simultaneously. Database architectures that are often utilized are flat, hierarchical, relational, and network. A database is an essential component of just about any flexible manufacturing system. The much more fundamental role of a database in an FMS is to store and make relevant data required to regulate the manufacturing. A FMS database is a critical component of a plan to protect the validity and dependability of knowledge in the FMS system. A database management system (DBMS) is a set of applications that allow centralized control to content contained in a system (Ranky, 1983; Nand , 1991; Groover, 2015).

\subsubsection{The Meaning of A Database In Flexible Manufacturing Systems (FMS)}

A database is an essential component of whatever flexible manufacturing system (FMS). The much more fundamental role of a database in an FMS is to store and make information available required to regulate the production processes. The database stores information required for virtually all FMS control functions. Databases allow the FMS to communicate with other computerbased manufacturing techniques including such Material Requirement Planning (MRP), Computer Aided Design (CAD), and Computer Aided Manufacturing (CAM). A database, like plants and equipment, must be seen as a strategic corporate resource. Also needs upkeep, personnel, and the periodic replacement of outmoded infrastructures, and it has the potential to produce money. It may be used for a variety of reasons, including quality control, productivity assessment, system design, machine usage optimization, simulation, and many more. Actual planning and Numerically Controlled (NC) component programming operations are carried out via software which makes utilization of the database as a resource and store of information. Databases may be built to make program operation much easier. Because each FMS database is adapted to the needs of the entrepreneurial venture, and because each firm is unique, each FMS database would remain unique (Ranky , 1983; Nand, 1991; Groover, 2015).

\subsubsection{Importance of A Database In the Flexible Manufacturing Systems (FMS)}

A Flexible Manufacturing Systems' (FMS) database is a critical component of a plan to maintain the authenticity and dependability of content in the FMS system. A database managing system (DBMS) is a set of applications that allow for synchronized access to data contained in a database. The most 
essential purpose of a DBMS is to combine knowledge such that conceptual linkages required for business operations are preserved. Furthermore, most DBMSs enable database record format independent from interface applications. A strategies are applied is regarded as a single organization. Many people could be created, each with a unique set of performance characteristics There is no centralized storage.A successful DBMS would handle many various types of storage arrangements, so that distinct sections of the database may be located in multiple methods, and the storage structure for a particular component could be modified as efficiency requirements change or grow properly understood. A strategies are applied is regarded as a single organization. Many people could becreated, each with a unique set of performance characteristics There is no centralized storage. A successful DBMS would handle many various types of storage arrangements, so that distinct sections of the database may be located in multiple methods, and the storage structure for a particular component could be modified as efficiency requirements change or grow properly understood. (EIMaragy, 1985; Diega et al., 1991; opions from author).

\section{Results and Discussion}

\subsection{Strength, Weakness, Opportunity, and Threat (SWOT) Analysis for Flexible Manufactıring Systems}

Strength, Weakness, Opportunity, and Threat (SWOT) evaluation (SWOT composite) is a comprehensive assessment approach utilized to assist a someone or enterprise in identifying strengths, weaknesses, opportunities, and threats in commercial rivalry or project preparation (Fundamental Analysis, 2021). Various applications are used in the analysis and making decisions of the strategic position of the enterprises. One of these applications is SWOT analysis. It is important for the success of the analysis process of internal and external factors within the making decision due to manufacturing system that the manufacturing companies plan to use and apply for producing manufacturing products and goods.

For SWOT Analysis, Internal environmental factors show their strengths and weaknesses, while external factors are classified as opportunities and threats. The goal of every studies is to determine the main internal and external components which are critical to achieving the goal. Internal characteristics are connected to strengths and weaknesses, whereas external variables are related to opportunities and challenges (Mendes et al., 2011; Keleş et al., 2018). This analysis is evaluted-applied and complied from the opions of the experts of this manuacturing systems, the literatür of this scientific field and opions of the a1uthor. SWOT Analysis for FMS is presented in Table 1.

Automation-controlled production system projects are low-risk, low-cost and non-invasive systems that are completed quickly without disrupting existing systems. It provides ease of implementation, scaling and management of artificial intelligence without any problems. It can support the feedback loop to distribute artificial intelligence to an unlimited number of robots with a single click, to perform version control and update, and to continuously improve. Automation-controlled manufacturing systems free employees from repetitive and unnecessary tasks, thus enabling employees to focus on more strategic initiatives. Manufacturing systems, which are a solution partner that supports sustainable growth and relieves employees from routine work, allow to increase productivity, reduce costs and facilitate compliance. 


\begin{abstract}
Strengths:
*Quickly adapting to changes in the form of products in the sector

* Technological sophistication, Vertical and horizontal

Technological interaction

*Service technology for devices, Security, policies and quality of services

* It saves space and reduces the number of employees while

increasing automation.

* It provides shortening of machine preparation times.

* Since it is a system that minimizes the human factor, it minimizes the number of errors.

* It enables the production of a wider variety of products in smaller batches, accelerates the financial cycle and minimizes heap volume.

* It increases the productivity of the employees and creates a safer work environment.

* It creates long-term competitive advantage by increasing productivity and profitability.

* It shortens the delivery time of orders and shortens the cycle time.
\end{abstract}

\section{Opportunities:}

Availability of product ingredients that can greatly improve the product range

* the emergence of each product depends on the production of different types of parts.

In order to produce different types of parts, it is necessary to constantly change the settings of the machines that will carry out the production.

* Production process flexibility is the ability to provide processes that can produce different products without making significant changes in the machinery and equipment that provide the production.

*production flexibility depends on the flexibility of the benches and material handling systems used, and the information and control system of the enterprises.

*As the demands, expectations and needs of the consumers are constantly changing, forcing the businesses to be active in product flexibility, it is necessary to use flexible production systems to ensure product flexibility.

*Route flexibility prevents production disruption and loss of time due to these

* Technologies have the ability to adapt to changes and innovations

* In addition to flexibility in production depending on the constantly changing market, business organizations also require adaptation to changes and innovations and provide organizational flexibility.

*New and flexible organizational structures create smaller structures, unlike classical hierarchical organizational structures.

\section{Weaknesses:}

* Expensive company locations

*Failure to reach the delivery on time

*The constant increase in product shipping costs

* Inability to make too many discounts

* Lack of capital

* Staying behind its competitors in terms of recognition

*Inadequacy of advertising campaigns

*Expensive raw material products

*High rate of substitution of the products it produces

*Requires continuous technological innovation

*Requires an expert team in installation and operation

*Deviations in planning in case of technical problems

*High installation costs

*Software issues

*It takes time for the system to fully settle

\section{Threats:}

*It is specially designed according to the needs of businesses. This means that it takes several years before a system is installed and running.

* The emergence of both direct costs such as machinery and equipment and many indirect costs in the establishment of the system.

*According to the principles of the system, the use of robots will become increasingly widespread, robots will take the place of human beings more and more, and this will bring unemployment.

* some machines are down, preventing the system from performing its functions.

* However, incorrect programming, unplanned tool changes can also cause disruptions in the realization of planned production.

\section{Conclusions and Recommendations}

Flexibility is a generated importance of the correct as the proportion of different kinds of products to the volume of a range or as the proportional of the time necessary for group of developers. There are numerous types of flexible manufacturing or ways to measuring flexibility, several of which are as regards. Structural flexibility reflects the chance that the database model would adjust to external variables, predicted working process, and disruptions in the production process. Structural flexibility encompasses both flow organization flexibility and structured analysis flexibility. Apply organizational, essentially reflects the chance that the provided production line will be successful.
Transformational adaptability of the system is determined by translating measurements of flexibility in the outcome into system components, yielding a matrix measurement of flexibility/system properties. Flexibility of framework inputs comprises the flexibility over all system components prior to the conversion: purchasing, providers, and transports. Flexible technical manufacturing decreases the period, expenses per unit of goods, facilitates production process and sensible use of the equipment campground, diminishes stock levels, raises worker productive capacity, facilitates empathetic, lightweight, and higher throughput, minimises employee exhaustion, and increases efficiency focused on the conception of a successful product line and name in the industry. 
Flexible manufacturing combines entire production streams with production interruption, i.e. exploits the benefits of both movements while attempting to avoid the problems of both movements. The goal is to maintain continuous material flows within production while maintaining maximum production flexibility. This indicates that the system could quickly react to the needs of each client, avoiding halting manufacturing, accumulating incomplete goods, and so on. manufacturers need to use advancements to achieve the maximum level of manufacturing automation feasible. In reality, the primary objective of automated processes is indeed not, as it once was, mass high production series of items at low premium, but rather the development of a flexible system capable of quickly meeting specific customer needs and allowing for effective and quick readjustment from one method of project to some other. This approach is the one which analytical frameworks to efficiently quickly react situations rather than being limited to two moments every year. This manufacturing system can increase efficiency and, as a result, decrease an industry's manufacturing expenses. Flexible manufacturing might be an important part of a justify making approach, allowing consumers to personalize the goods customers desire. Such adaptability might come at a larger initial investment.

\section{Acknowledge}

I would like to thank the business officials, business employees and experts who helped me within the scope of the research by sharing their valuable information.

\section{References}

Alla, H., Ladet, P., Martinez, J., and Silva, M.(1985). Modelling and Validation of complex systems by colored Petri Nets: Application to a Flexible Manufacturing System, Advances in Petri Nets", Lecture Notes in Computer Science, 188, Springer Verlag, Berlin, 15-31.

Askin, Ronald G.., Charles R. Standridge, Charles R.. Standridge (1993). Modeling and Analysis of Manufacturing Systems, John Wiley and Sons Incorporated, $461 \mathrm{p}$.

BaneIjee, S.K. and AI-Maliki, I. (1988). A structured approach to FMS modelling, International Journal of Computer Integrated Manufacturing, 1(2), 77-88.

Banker,S. (2018). Transitioning to Flexible Assembly Lines, https://www.forbes.com/sites/stevebanker/2018/06/04/transit ioning-to-flexible-assembly-lines/?sh=4a63de6541e0, Jun 4, 2018

Barad, M. (1992). Impact of some flexibility factors in FMSs - a performance evaluation approach", International Journal of Production Research, 30(2), 2587-2602.

Barash, M.M. (1982). Computer Manufacturing Systems for discrete products, The Handbook of Industrial Engineering, John Wiley and Sons.

Bard, Y. (1979). Some extentions to multiclass queueing network analysis, Performance of Computer Systems (M. Arato. Editor) North-Holland, Amsterdam, 1979.

Barry, L.J. (1986). Introduction to Computer Numerical Control, Pitman, London, New York : Wiley, 245 p.
Barutçuoğlu, Ş. and Azizoğlu, M. (2011). Flexible assembly line design problem with fixed number of workstations. International Journal of Production Research, 49(12), 36913714. doi:10.1080/00207543.2010.492410.

Baskett, F., Chandy, K.M., Muntz, R.R., and Palocios, F.G. (1975). Open, Closed and Mixed Networks of Queues with different Class of Customers, Journal of Association for Computing Machinery, 22(2), 248-260.

Berry, W.L. and Cooper, M.C. (1999). Manufacturing flexibility: methods for measuring the impact of product variety on performance in process industries", Journal of Operations Management, 17(2), 163-78

Bowden, R., and Browne, J. (1991). Approach to the production environment design task within factory coordination", Computer Integrated Manufacturing Systems, 4(1),42-50.

Browne, J., Harden, J., and Shivnan, J.,I. (1990). Production Management Systems: A elM Perspective, Addison Wesley Publishing, 1990.

Browne, J., Dubois, D., Rathmill, K., Sethi, S. P. and Stecke, K. E. (1984). Classification of flexible manufacturing systems. The FMS Magazine, 114-117.

Buzacott, J. A.(1983). Modelling Automated Manufacturing System, Fall Industrial Eng. Conference Proceedings, 341348.

Cutkosky, M.R., Fussell, R.M., and Milligan, Jr., R. (1984). The design of a flexible machining cell for small batch production, Journal of Manufacturing Systems, 3(1), 39-59.

EIMaragy, H.A., (1985). Automated Tool Management in Flexible Manufacturing", Journal of Manufacturing Systems, $4(1), 1-13$.

Flexible Manufacturing System, https://www.mechtalk.info/2018/11/flexible-manufacturingsystem-fms.html. (Access Date: 21.08.2021)

Fundamental Analysis, https://www.investopedia.com/terms/s/swot.asp, (Access Date: 21.08 .2021 )

Gordon, WJ. and Newell, G.F.(1967). Closed queueing networks with exponential servers, Operations Research, 15, 254-265.

Grant, T.(1986). Categories of Contraints in Acquiring Planning and Scheduling Knowledge, Alvey Project -Report.

Groover, M. P. (2015). Automation, Production Systems, and Computer-Integrated Manufacturing 4th Edition, Pearson, $811 \mathrm{p}$.

Hannam, R. G. and Talavage, J.(2020). Flexible manufacturing systems in practice design, analysis and simulation, p.15-28, CRC Press, $377 \mathrm{p}$

Hitomi, K. (1996). Manufacturing Systems Engineering A Unified Approach to Manufacturing Technology, Production Management and Industrial Economics , Second Edition, Taylor \& Francis Inc, CRC Press, 557 p.

Hitomi, K. (1994) Moving toward manufacturing excellence for future production perspectives, Industrial Engineering, 26 (6), 48-50. 
Jackson, J.R. (1962). Job Shop like queueing systems, Management Science, 10, 131-142.

Johnson, L.A. and Montgomery, D.C. (1974). Operation Research in Production Planning, Scheduling and Inventory Control, John Willey and Sons, New York, NY, 1st edition, $544 \mathrm{p}$.

Keleş, M., Kılıç, Ü. and Keleş, A. (2018). E- Ticarette Pazar Araştırması ve SWOT Analizi. El-Cezeri Fen ve Mühendislik Dergisi, 5(2), 569-604.

KouveJis, P. (1992). Design and planning problems in flexible manufacturing systems: a critical review, Journal . of Intelligent Manufacturing, 3, 75-99.

La Diega, S.N., Passannati, A., and Passannati, G. (1991). Optimum tool replacement policies in integrated manufacturing systems, Computer Aided Production Engineering, Elsevier, (Eds.V.C. Venkatesh and J.A.McGeough), 15-332.

Law, A. (1988) Simulation of Manufacturing Systems, Proceedings of the 1988 Winter Simulation Conference, 4051 (M. Abrams, P. Haingh and J. Comfort Editors.)

Luggen, W.W. (1991). Flexible Manufacturing Cells and Systems. Prentice-Hall, Englewood Cliffs, NJ.

Luger, G.F., and Stubblefield, W. A. (1989). AI and Design of Expert Systems, Benjamin/Cummings Publication Company, California.

McGinnis, L. (1989) Flexible manufacturing. In: White, J., Pence, I.W. (Eds.), Progress in Material Handling and Logistics, 1, Springer-Verlag, Berlin, p. 247

Mendes, J. M., Leitao, P. and Colombo, A. W. (2011). Serviceoriented computing in manufacturing automation: A SWOT analysis. 2011 9th IEEE International Conference on Industrial Informatics. doi:10.1109/indin.2011.6034900

Methods of production, https://www.bbc.co.uk/bitesize/guides/zth78mn/revision/2, (Access Date: 10.09.2021).

Merchant, M. E. (1961). The Manufacturing System Concept in Production Engineering Research. In: Annals of CIRP, 7783.

Merchant, M. E. (2000). The Future of Manufacturing. In: Handbook of Industrial Automation (Shell, Richard L. and Hall, Ernest L. Editor), Marcel Dekker, Inc., Cincinnat.

Merchant, M.E. (1983). Current Status of Potential for Automation in the Metalworking Manufacturing Industry, Annals of the CIRP, 32(2), 519-523.

Michalos, G., Sipsas, P., Makris, S. and Chryssolouris, G. (2016). Decision making logic for flexible assembly lines reconfiguration. Robotics and Computer-Integrated Manufacturing, 37, 233-250. doi:10.1016/j.rcim.2015.04.006

Nand K. Jha (Editor) (1991). Handbook of Flexible Manufacturing Systems, Elsevier Science, Academic Press, Inc., 332 p.
Newell, A. and Simon, H. (1963). GPS, A Program that simulate human though, Computer and Thought, E.A. Feingbaum and J. Felman(Eds.), McGraw-Hill, N.Y.

Newman, S.T., (1990). An Integrated approach to the Design and evaluation of Flexible Machining Cells, PhD Thesis, LUT.

Qiao, G., Robert Lu, R. And Mclean, C. (2006). Flexible manufacturing system for mass customization manufacturing", International Journal of Mass Customisation, 1(2/3), 374 - 393

Ranky, P.G. (1983). Design and Operations of Flexible Manufacturing Systems, IFS Publications.

Reiser, M. and Lavenberg, S.S. (1980). Mean-value analysis of closed multi-chain queueing networks, Journal of ACM, 2782), 313-323.

Sawik T. (1999) Production Scheduling in Flexible Assembly Lines. In: Production Planning and Scheduling in Flexible Assembly Systems. Springer, Berlin, Heidelberg. https://doi.org/10.1007/978-3-642-58614-9_6.

Schorer, B.I., and Tseng, F.T. (1987). Modelling Complex Manufacturing Systems using Simulation, Proceedings. of the 1987 Winter, Simulation Conf. A.Thesen, H.Grant, W. D. Kelton, (editors), 677-682

Schweitzer, PJ. (1977). Maximum throughput in finite capacity open queueing networks with product form solutions, Management Science, 24(2), 121-240.

Shivanand, H.K., Benal, M.M. and Koti, V. (2006). Flexible Manufacturing System, New Age Publications, 165 p.

Simplicable, $\quad$ https://simplicable.com/new/job-production (Access Date: 10.09.2021).

Stecke, K. E., and Kim, I.(1986). A fexible approach to implementing the short-term FMS planning function, Proceeding of 2nd. ORSA/TIMS Conference on FMS: OR Models and Application, Editors. K.E. Stecke and R. Suri, Michigan, 283-295.

Solberg, J.J. (1979). Computer Models for Design and Control of Flexible Manufacturing Systems, 16th NCS, 111-117.

Solberg, U. (1978). Quantitative design tools for computerized manufacturing systems, Proceedings of 6th North American Metalworking research committee, Florida.

Solberg, J.J. (1976). Optimal Design and Control of Computerized Manufacturing Systems, Proceedings of AIIE Systems Engineering Conference.

Solberg, J.J. (1979). Computer Models for Design and Control of Flexible Manufacturing Systems, 16th NCS, 111-117.

Solberg, J.J. (1982). Mathematical Design tools for integrated production systems, Production 23rd MTDR Conference.

Spur, G., Seliger, G and Viehweger, B. (1986). Cell Concepts for flexible automated manufacturing, Journal of Manufacturing Systems, 5(3), 171-179.

Stecke, K.E. (1983). Formulation and solution of nonlineer Integer Production Planning for Flexible Manufacturing Systems, Management Science, 29(3), 273-288. 
Suri, R. and Hildebrant, R.R. (1984). Modelling flexible manufacturing systems using mean-value analysis, Journal of Manufacturing Systems, 3(1), 61-69.

Tetzlaff, Ulrich A.W. (1990). Optimal Design Of Flexible Manufacturing Systems, Springer-Verlag Berlin -PhysicaVerlag Heidelberg, 1th edition, 190p.

Types of production, https://theintactone.com/2019/06/16/pomu1-topic-2-types-of-production-systems/

What is job production process? https://askinglot.com/what-isjob-production-process (Access Date: 21.09.2021)

Wang, W. (1989). A Knowledge based modelling system for the design and evaluation of flexible manufacturing facilities, PhD Thesis, LUT.

Yang, T., Peters, B. A. and Tu, M. (2005). Layout design for flexible manufacturing systems considering single-loop directional flow patterns. European Journal of Operational Research, 164(2), 440-455. doi:10.1016/j.ejor.2003.04.004.

Young, R.E. and Mayer, R. (1984) The information dilemma: to conceptualize manufacturing as information process, Industrial Engineering, 16 (9), 28-34.

Zhang, P.(1989). The Management of Tool Flows in Flexible manufacturing Systems for Cylindrical Pans, PhD Thesis, LUT.

5 Principles of Flexible Assembly Line Design, https://www.automationworld.com/home/blog/13318850/5principles-of-flexible-assembly-line-design (Access Date: 11.09.2021). 